\title{
原著
}

\section{急性骨髄性白血病，ハイリスク骨髄異形成症候群に対する 初回同種移植50症例の後方視的解析}

\author{
安藤寿彦，中邑幸伸，縄田涼平，高橋＼cjkstart徹，三谷紀之，山下浩司，田中芳紀， \\ 田中真由美，有好浩一，野見山淳，鶴 政俊，湯尻俊昭，谷澤幸生 \\ 山口大学大学院医学系研究科病態制御内科学分野（内科学第三）宇部市南小串 1 丁目 $1-1$ （ 7 755-8505）
}

Key words：急性骨髄性白血病，骨髄異形成症候群，同種移植，染色体異常

和 文 抄 録

我々は2002年 4 月から 2009 年 1 月までに初回同種 移植を施行した，急性骨髄性白血病 (40症例)，八 イリスク骨髄異形成症候群（10症例）計50症例につ いて, 移植前・移植時予後因子を検討するために後 方視的解析を行った。平均年齢は 41.4 歳. $32 \%$ が移 植時非寛解期であり，また $44 \%$ 染色体リスク分類 において予後不良群であった． 3 年の全生存率，無 進行生存率, 再発率, 移植関連死亡率はそれぞれ $48.8 \% ， 41.3 \% ， 38.9 \% ， 27.8 \%$ であった。移植前・移 植時因子の予後に与える影響を単変量・多変量解析 で検討し，染色体リスクが最も重要な因子として同 定された。ささら，染色体リスクで層別化し解析を 加えたところ, 染色体リスクによって, 移植前処置 の強度抢よび移植片対宿主病の対応を変更する, 層 別化治療の検討が必要と考えられる結果を得たので 報告する．

\section{緒言}

急性骨髄性白血病 (AML)，ハイリスク骨髄異形 成症候群（high risk-MDS）に対する同種移植は, 治癒を期待できる治療法として確立している。 しか し, AML, high risk-MDSに同種移植を施行して
も比較的高率の再発および移植関連死を認め, 平成 20 年度のJapan Society for Hematopoietc Cell Transplantation（JSHCT）の報告では，AML，骨 䚙異形成症候群 (MDS) の同種移植の 5 年全生存 （OS）はそれぞれ $55.4 \% ， 48.9 \%$ と報告されている. 移植成績には多様性があり，このことは疾患特性お よび患者因子の影響を受けているものと考えられ る.よって, 同種移植の成績に影響を与える疾患特 性・患者因子を検討し，それによって層別化した患 者グループ毎に状態にあった移植方法を選択するこ とは重要である。このような, リスクファクターに よる層別化治療は, 急性白血病, MDSや悪性リン パ腫の化学療法・支持療法においては一般的である が1-3), 化学療法での予後因子が同種移植において も同様に予後に影響を与えるか否か評価はまだ定ま っていないものが多い.さらに, 化学療法と異なり, 同種移植療法の領域では, 層別化療法は一般的には なっていない. しかしながら, 現在, 幹細胞源や移 植前処置の多様化, 免疫抑制剂 - 移植後合併症治療 薬の進歩に伴い, 同種移植においても化学療法と同 様に治療の層別化が可能な状況になってきていると 考える，今回我々は，AMLおよびhigh risk-MDS に対する同種移植前および移植時のリスクファクタ 一を後方視的に解析して, 予後因子を抽出し, 抽出 された因子での同種移植法の層別化の可能性を検討 したので報告する.

平成 22 年 3 月 9 日受理 
方法

\section{1）患者および治療背景}

当科では，2002年 4 月から 2009 年 1 月までに計 52 症例のAMLおよびhigh risk-MDSに対し初回同種 移植を施行した。このうち臍带血移植後一次性生着 不全をきたした 2 症例は解析から除外し，50症例の 解析となった. 50 症例のまとめは表 1 に示している. 後方視的解析であり, 移植時病期, 移植前処置強度, 移植幹細胞源, 移植片対宿主病 (GVHD) 予防など は多岐に及んでいる。

移植時病期では，非寛解期が16症例，染色体リス ク (AML ; National Comprehensive Cancer Network：NCCNのガイドライン分類, MDS ; $\left.\mathrm{IPSS}^{21}\right)$ では，予後不良異常が22症例と高率であっ た. Hematopoietic cell transplantationcomorbidity index (HCT-CI) ${ }^{4)}$ については, 呼吸 機能でのDLCOはすべての症例で未施行であり, 肺 機能を評価項目から除外して検討している，移植前 処置については，全身放射線照射（TBI） $12 \mathrm{~Gy}+$ シ クロフォスファミド (CY) $120 \mathrm{mg} / \mathrm{kg}$ 抢よびブス ルファン $(\mathrm{Bu}) 16 \mathrm{mg} / \mathrm{kg}$ (静注用Buでは $12.8 \mathrm{mg} / \mathrm{kg}$ ) $+\mathrm{CY} 120 \mathrm{mg} / \mathrm{kg}$ の従来施行されてきた骨䯣破壊的 前処置またはそれ以上の強度を持つものをFullと規 定し, それ以下の強度のものは, Reduced intensity conditioning（RIC）と規定した。このた め，RICにはTBI 8 Gyなど一般に言われているRIC より強度が強い前処置を含んでいる。この規定によ るとFull 27症例, RIC 23症例であった. HLAの GVHD方向のミスマッチについては, 臍帯血では

表 1 患者・治療背景

\begin{tabular}{|c|c|}
\hline \multicolumn{2}{|r|}{ 费者-治撰背景 } \\
\hline 年秢 & 平均 $41.4(16-62)$ \\
\hline 性别 & 男性 : 女性 $=30: 20$ \\
\hline 疾患 & 急性骨踷性白血病 $(n=40)$ FAB分頪 \\
\hline & MO: $1, M 1: 7, M 2: 8, M 3: 2, M 4: 4, M 4 e: 1, M 5: 1, M 6: 1$, TLD: 12, MNKK 3 \\
\hline & $\begin{array}{l}\text { 骨髓䔬形成症候群 }(n=10) \text { FAB分類 } \\
\text { RAEB1 }\end{array}$ \\
\hline 病期 & 第1䔈解期: 22 ，第2䔈解期: 12 ，非寛解期: 16 \\
\hline \multicolumn{2}{|c|}{ 染色体リスク (AML; NCCN, MDS; IPI) } \\
\hline \multicolumn{2}{|c|}{ 良好群: 13 ，中間群: 15 , 不良群: 22} \\
\hline 前䞘置 & Full: 27, RIC: 23 \\
\hline 幹細胞源 & 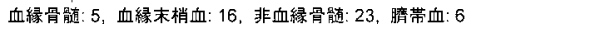 \\
\hline HLA GVH di & ection \\
\hline & 湾带血以外 match: $36,1 \mathrm{mis}: 8$ \\
\hline & 腾带血 1 mis: $2,2 \mathrm{mis}: 4$ \\
\hline 稳植紐胞数 & 血縁骨髄 平均 $2.98 \times 10^{8} / \mathrm{kg}$ ANC (1.94-3.8) \\
\hline & 血縁末梢血 平均 $4.25 \times 10^{5} / \mathrm{kg} \mathrm{CD} 34+$ cell $(2.73-7.48)$ \\
\hline & 非血縁骨䯣 平均 $2.58 \times 10^{8} \mathrm{~kg}$ ANC $(1.16-4.58)$ \\
\hline & 眃带血 平均 $2.87 \times 10^{7} / \mathrm{kg}$ ANC (2.26-3.6) \\
\hline GVHD予防 & 予防なL(同系): 1，CsA单独: 1 ，CsA+MTX: 13，FK+MMF: $1, F K+M T X: 34$ \\
\hline $\begin{array}{l}\text { aGVHD } \\
\text { cGVHD }\end{array}$ & $\begin{array}{l}\text { grade } 0: 13, I: 12, \| 1: 14, I I: 5,5, I V: 2, N . E .4 \\
\text { なL: } 18 \text {, Limited: 6, Extensive: } 17, \text { N.E. } 9\end{array}$ \\
\hline
\end{tabular}

HLA ミスマッチに伴う免疫反応が他の幹細胞源と 比較して弱いとされているので分けて記載してい る. 臍带血以外でも 44 症例中 8 症例 (18\%) がミス マッチと比較的高率であった，GVHD予防について は，血縁ドナーでHLAマッチの場合，通常 cyclosporin A (CsA) +methotrexate (MTX), 臍 带血を含む非血縁ドナーおよび血縁ドナーHLA GVHD方向ミスマッチの場合, tacrolimus（FK） +MTXを基本として選択しており，この 2 者が大 部分を占めた. GVHDは, 移植後28日以上生存し 100日以内に発症したものを急性GVHD（aGVHD） とし，100日以降のものを慢性GVHD（cGVHD）と した．重症度分類については，aGVHDについては 1994年に開かれた重症度に関する consensus conferenceで提唱された分類 ${ }^{5}$, cGVHDについては Shulmannらによって提唱された分類() に従った.

\section{2）統計方法}

デー夕解析は，2009年 4 月31日を最終観察日とし て行った，OSは，移植日から死亡までとし，生存 例は最終観察日をセンサーした. 無進行生存 (PFS) は, 移植日から再発, 進行, 死亡のうちいずれかを 最初に生じた日とし, 寛解生存例をセンサーした。 再発率（RR）は部位を問わず再発したものとし, 移植関連死亡 (TRM) は, 原病の再発・進行を伴 わない死亡と規定した，統計解析は, StatMate III (ATMS Co., Ltd., Tokyo, Japan) を使用して行っ た. OS, PFS, RR, TRMはKaplan and Meier法 で計算し，移植前および移植時因子の影響について は, Log-rank testで単変量解析を行い, これで $\mathrm{p}<0.2$ の結果を得た因子については, Cox regression modelで多変量解析を行った. 因子とし ては, 年齢 (40歳未満 vs 40歳以上), 病期 (第 1 寛解 vs 第 1 寛解以外), 染色体リスク（良好 +中 間vs 不良), 前処置 (Full vs RIC), 幹細胞源（血 縁 vs 非血縁), HCT-CI (0 vs 1 以上), GVHD方 向HLA合致度（マッチ vs ミスマッチ）を挙げて解 析した.

結果

\section{1）患者および治療背景}

患者および治療背景は，表 1 に要約する，移植前 
処置の内容は, 表 2 に示すように, Full移植では, TBI $12 \mathrm{~Gy}+\mathrm{CY} 120 \mathrm{mg} / \mathrm{kg}$ の TBIレジメが優位で, RICについては，一般的な意味でのRISTの代表的 レジメであるフルダラビン+アルキル化剤は少数 で，それにTBI $4-8 \mathrm{~Gy}$ 加えて強化したものが 大部分である。平均移植幹細胞数については表 1 に 示した通りであるが，非血縁骨髄での 2 症例は目標 細胞数の $2 \times 10^{8} / \mathrm{kg}$ を下回る $1 \times 10^{8} / \mathrm{kg}$ 前半の少な い輸注有核細胞数であったが，その他は十分な細胞 数を移植可能であった．HCT-CIでの陽性項目の大 部分は，感染症に対する静注抗生剂の継続使用と肝 機能異常であった.

\section{2) GVHDについて}

aGVHDについては，移植後28日までに死亡し評 価不能の 4 症例を除いた 46 症例で評価し, gradeIIIV 21 症例 $(46 \%) ，$ III-IV 7 症例（15\%）の発症率 であった。 cGVHDについては，評価可能41症例中 17症例（41\%）に広汎型を認めた。

\section{3) OS, PFS, RRとTRM}

3 年間のOS, PFS, RR, TRMはそれぞれ，48.8\%, 41.3\%，38.9\%，27.8\%であった. Kaplan and Meier curveを図 1 a, 1 bに示す．最終観察時で50症例中 16 症例に再発，12症例に移植関連死亡を認めた，再 発形式は10症例（63\%）が骨䯣再発， 2 症例 $(13 \%)$ が骨髄・髄外同時期再発， 4 症例 (25\%) が骨髄再 発を伴わない䯣外再発であった，移植関連死亡原因 は, 6 症例 (50\%) が感染症, 2 症例 (17\%) がGVHD, 3 症例 $(25 \%)$ が移植関連微小血管障害， 1 症例

表 2 前処置内容

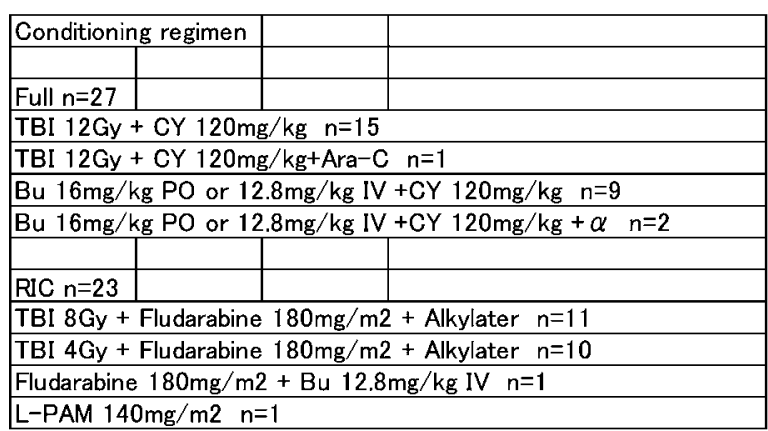

RICのアルキル化剤は、Bu $8 \mathrm{mg} / \mathrm{kg}$ po/6.4mg/kg iv, L-PAM $140 \mathrm{mg} / \mathrm{m} 2, \mathrm{Cr} 120 \mathrm{mg} / \mathrm{kg}$ など。

TBI：全身放射線照射， CY : シクロホスファミド, $\mathrm{Bu}$ ： ブスルファン, Alkylater：アルキル化剂, L-PAM : メル ファラン, PO : 経口投与, IV : 静脈注射
（8％）が出血であった.

\section{4）予後因子解析}

OS, PFS，RR，TRMについての単変量・多変量 解析の結果については表 $3 ， 4$ にまとめて示す.

OSについての, 移植前・移植時因子の単変量解 析の結果, 患者年齢 40 歳以上 - 第 1 寛解期以外 - 予 後不良の染色体異常が $\mathrm{p}<0.05$ で有意に予後不良な因

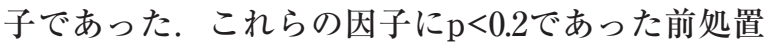
の因子を加え多変量解析を行ったところ，予後不良 の染色体異常のみが $\mathrm{p}<0.01$ と有意な因子として同定 され，そのrisk ratioは3.617であった。

PFSについての解析では，単変量解析で第 1 寛解 期以外 $(p<0.05) \cdot$ 予後不良の染色体異常 $(\mathrm{p}<0.01)$ は有意な予後不良因子であり，これらの因子に $\mathrm{p}<0.2$ の因子を加え多変量解析を行ったところ，第 1 寛解期以外（ $p<0.05 ）$ と予後不良染色体異常 $(p<0.01)$ で予後不良因子として同定された.

表 3 全生存, 無進行生存, 再発率, 移植関連死亡の移 植前・移植時因子の単変量解析

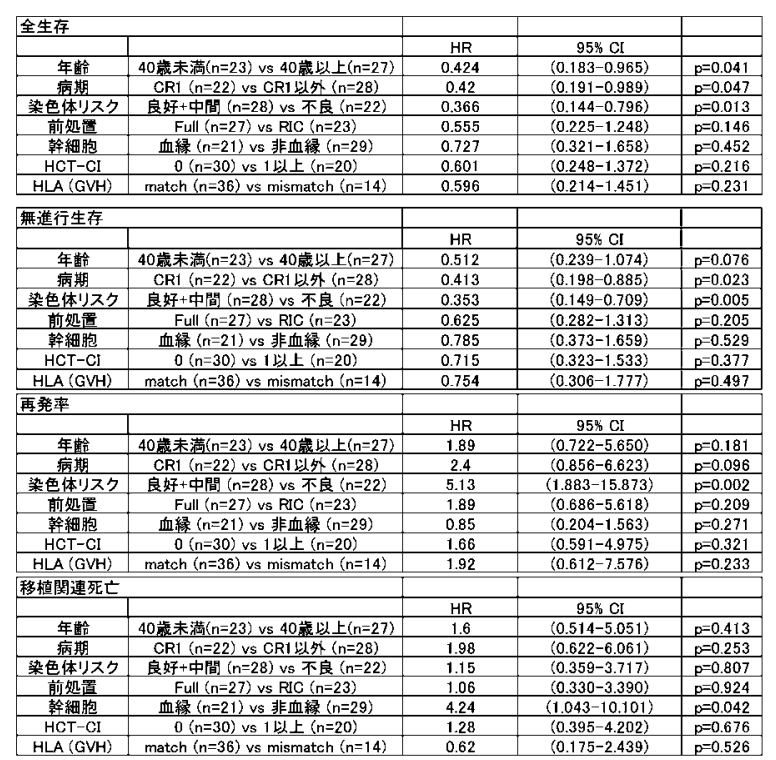

表 4 全生存率，無再発生存率，再発率の移植前・移植 時因子の多変量解析

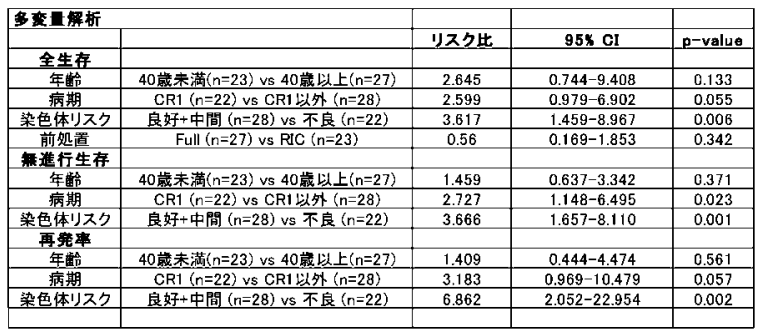



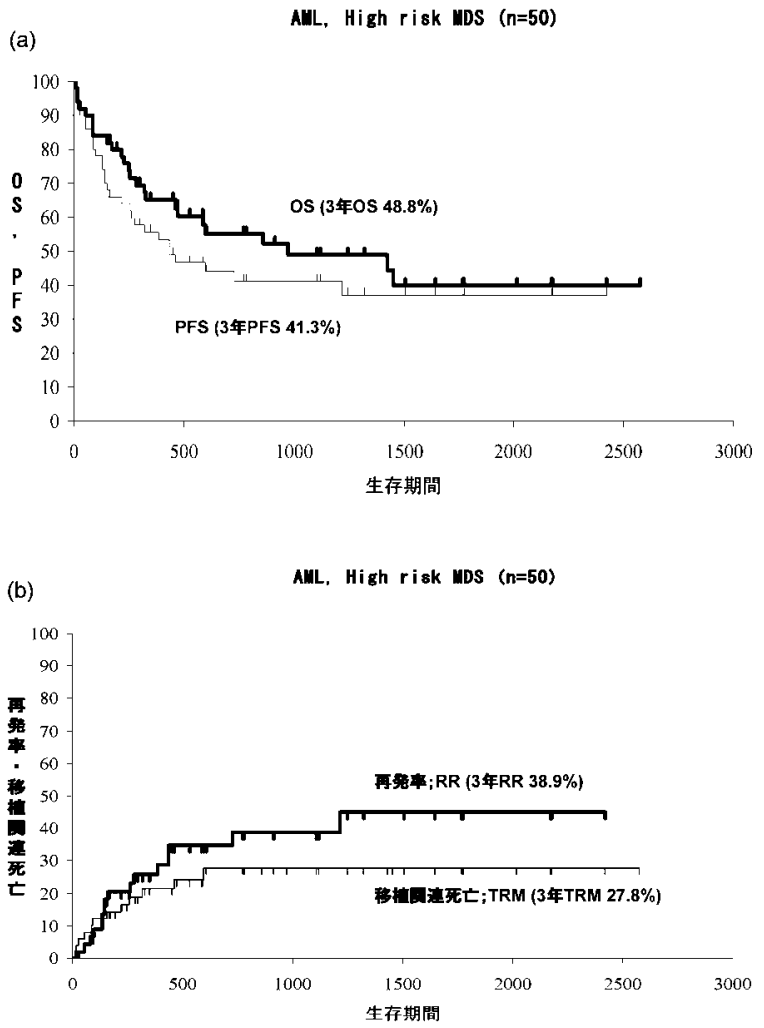

図 1 (a) 太線：全症例での全生存 $(\mathrm{OS})$, 細線：全症 例での無再発生存（PFS）（b）太線：全症例での 再発率 (RR), 細線：全症例での移植関連死亡 (TRM)

RRについての解析では, 単変量解析で予後不良 の染色体異常（p=0.002）のみが有意な因子であっ た. $\mathrm{p}<0.2$ の因子を加え多変量解析を行ったが, や はり予後不良の染色体異常のみが $\mathrm{p}<0.01$ で有意な因 子として同定された。移植時病期の影響は $\mathrm{p}=0.057$ でmarginalな結果であった.

TRMについての解析では, 単変量解析で非血縁 ドナーからの移植のみが $\mathrm{p}<0.05 て ゙$ 有意な因子として 検出された.この因子以外に $\mathrm{p}<0.2$ の因子は認めず 多変量解析は行わなかった。

\section{5 ）染色体リスクによるサブグループ解析}

染色体異常による層別化によって，移植前処置の 強度をどのように設定し, 移植後免疫反応 $(\mathrm{aGVHD}$, cGVHD）をどのようにマネージメントすべきかを 検討するため, サブグループ解析を行った（染色体 予後良好群 +中間群を good risk group, 染色体予 後不良群をpoor risk groupと規定した). 移植前処 置の強度については, good risk group・poor risk groupともに, PFSにおいてLog-rank testで有意な (a)
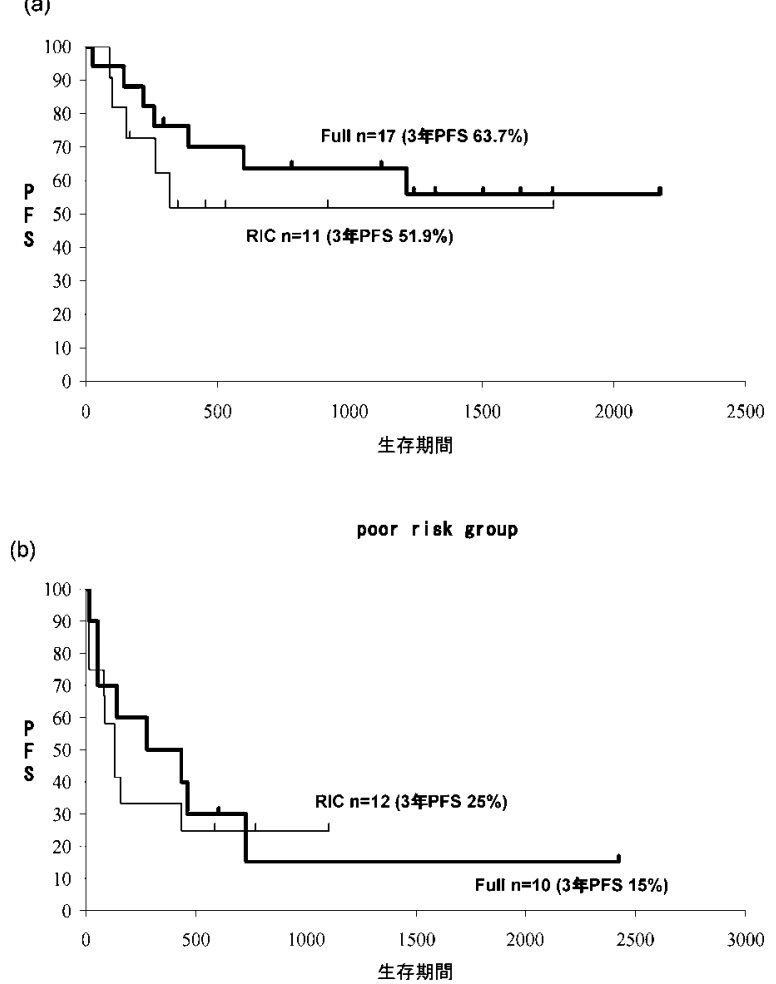

図2 染色体リスク別（染色体予後良好群＋中間群を good risk group, 染色体予後不良群を poor risk group と規定) の前処置強度での無再発生存 (PFS). 太線：Full, 細線：RIC.（a）good risk groupの前 処置強度別無再発生存率（PFS）（b） poor risk group $の$ 前処置強度別無再発生存率 (PFS)

影響はなかった（図 2 ). RRについても, データは 示さないが前処置強度の影響はなかった。 aGVHD のPFSに与える影響については，データは示さない が, good risk groupでは, aGVHD 0-Iの方がII-IV と比較して有意にPFS良好 $(\mathrm{p}=0.011)$ で, poor risk groupでは, 0-I vs II-IVで有意差なしであった. cGVHDについてはgood risk groupでは, $\mathrm{p}=0.07$ と marginalな結果であったが，限局型以下のほうが PFS良好な結果であり, poor risk groupでは, 広沉 型が有意（ $\mathrm{p}=0.003 ） に P F S$ 良好な結果であった (図 3 ). GVHDのRRに与える影響についてデー夕 は示していないが, good risk groupについては, aGVHD, cGVHDともに有意差なし, poor risk groupについては, aGVHDは有意差なしであった が, cGVHDについては広沉型の方が有意 $(\mathrm{p}=0.009)$ に再発を抑制する結果であった。 


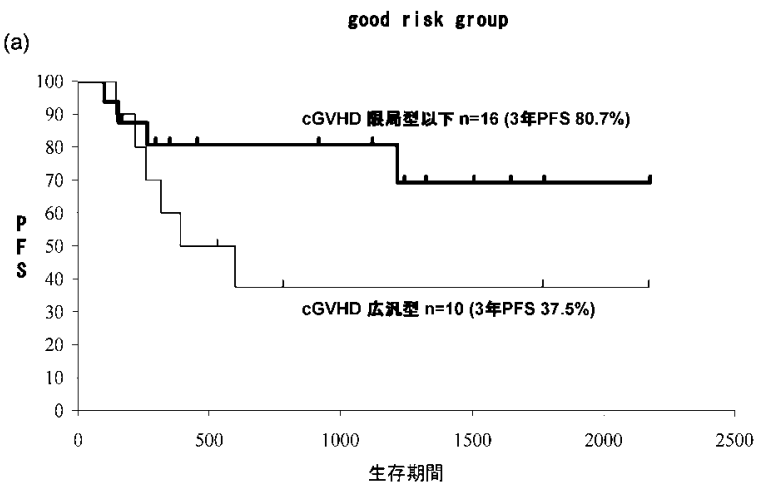

(b)

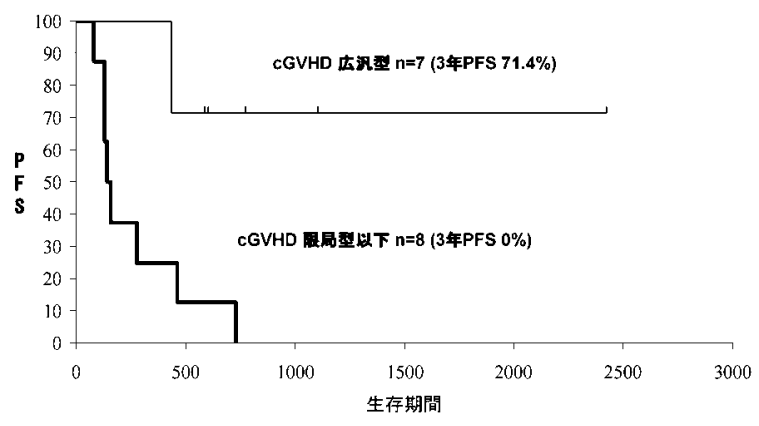

図３染色体リスク別（染色体予後良好群＋中間群を good risk group, 染色体予後不良群を poor risk groupと規定）のcGVHD重症度での無進行生存 (PFS)。（a）good risk groupでのcGVHD重症度別 太線：限局型以下，細線：広沉型（b） poor risk groupでのcGVHD重症度別太線：限局型以下， 細線：広沉型

\section{考察}

最初に, 当科でのAML, high risk-MDSに対す る同種移植療法の基本方針を以下 (1)～(3)に示す. (1) 同種移植患者の年齢上限は65歳以下とする。(2)病期 については寛解期移植を目指すが, 病勢の緩徐な寛 解導入困難症例に対しては，血縁HLAマッチドナ 一が得られない場合, HLAミスマッチ（通常は 1 座ミスマッチまで）血縁ドナーや臍帯血を用い非寛 解期移植を積極的に施行する。(3)移植前処置につい ては，可能なら基本的には強度をできるだけ保つも ので施行する.このような方針から, 今回の解析で は，非寛解期移植および予後不良染色体異常をもつ 患者が多く含まれている，また，RIC群では，従来 のフルダラビンなどのプリンアナログ+アルキル化 剂の強度よりも強化したものが大部分であるという 特徴が確認される。 TRMについては，これまでの 報告で相関があるとされるHCT-CIについては呼吸
機能検査項目を除外したことや, HCT-CI 3 点以上 の高リスク群が少なく 0 点と 1 点以上に分けて解析 せざるを得なかったことなど問題点がある. 今回示 した成績は上記患者・治療背景の特徵を考慮して検 討する必要がある。

今回は後方視的解析であり, 病期・前処置・移植 幹細胞源など限定しておらず，また症例数も限られ ているため, OSやPFSなどはあくまで参考值と考 えざるを得ない，我々は今回特に染色体リスクの同 種移植成績に与える影響について注目した。 その理 由は，化学療法における染色体リスク分類が，同種 移植後の成績にもよく反映されるか否か見解が定ま っていないからである. 我々の解析では, OS, PFS, RRにおいて予後不良の染色体異常が最も重要な因 子として同定された．また，TRMにおいて同因子 が有意な因子でなかったことを考えると, 予後不良 染色体異常の再発に与える影響が重要であると考察 される。これまでの報告では，移植時病期が再発に 重要な因子であるとの報告が多い7-8)、染色体異常 は化学療法での寛解導入の可否・再発について関連 の強い因子であるため, 病期が重要視されている可 能性がある. 今回は, 染色体予後良好群と中間群を まとめて解析しているが, 良好群・中間群・不良群 の 3 群に分けた検討で, 良好群と中間群のRRは同 等で, 不良群のみ高率であった結果をもって 2 群間 の比較とした.つまり, 染色体リスク中間群の再発 は, 同種移植により良好群と同程度に抑えられるが, 不良群に対しては再発を十分に抑えられない可能性 を示唆する。同種移植療法に限定しない治療での染 色体異常の予後への関与については，AML，MDS ともに数多くの大規模臨床試験が行われており, AMLでは, Southwest oncology Group (SWOG) 9) とMedical Research Council (MRC) 10) がその代 表的なものである. 今回の染色体リスク分類には, NCCNのガイドラインをもとに分類したが, 11q23 異常分類や複雑染色体異常の定義など若干の差異は あるものの概ね共通している.我々の報告と同様に, 予後不良の染色体異常を持つAMLに対して同種移 植を施行しても高いRRを報告しているものとして， MRCの報告 ${ }^{10)}$ がある. adverse riskの患者で第 1 寛 解期に同種移植を施行した症例は，13症例と少数例 であるが， RRが77\%と高率であった。同様に Ferrant $ら$ European Group for Blood and Marrow 
Transplantationの報告11) でも，5番染色体異常・ 7 番染色体異常・Hypodiploidなどの予後不良の染 色体異常をもつAMLは第 1 寛解期で同種移植を施 行しても自家移植と予後が変わらず高いRRを報告 している。一方，小川らJSHCTの第 1 寛解期に限 局したAML患者群の報告 ${ }^{12)}$ では，16症例と少数で はあるが，第 1 寛解期に導入していれば，予後不良 染色体異常を持つ症例でも血縁同種移植で RR $33.7 \%$ と比較的良好に再発を抑制している。これら の報告と我々の報告の大きな違いは，症例を第 1 寛 解期に限定しているか否かである。染色体リスク良 好群・中間群は寛解導入療法によって通常 $80 \%$ 以上 の寛解導入が達成される。しかし，予後不良群では 50-60\%と寛解導入率が低く，また寛解導入に一旦 成功しても短期再発が多いため, 血縁ドナーが得ら れない場合は，非血縁ドナーを寛解状態で待てない 症例も多い，寛解期移植にこだわるならば，一般的 に他の幹細胞源と比較して成績の劣る臍帯血移植を 施行することになることが多い.つまり，染色体予 後不良群での第 1 寛解期の移植というのは，大きな バイアスがかかっていることが想定され，良好なバ イアスがかかっている状態での同種移植によっても 高いRRを報告しているものが多いということであ る。我々の報告同様，移植時病期を限定しない AMLでの解析としては, JSHCTの報告 ${ }^{13)}$ がある. SWOGの染色体リスクに準じて分類し, 予後不良 群は56\%と高いRRを報告している.

今回は，化学療法を主体とした治療での予後を反 映する染色体リスク分類をベースに検討を行ってい るが, 同種移植においては抗癌剤感受性だけでなく, 腫瘍免疫に対する感受性も重要であることが予想さ れる. Armandらは ${ }^{14)}$ ，第 1 寛解期で同種移植を施 行したAML・MDSで， 3 症例以上認められた染色 体異常のリスク層別化を行っている.この報告では, 5 番または 7 番単独の染色体異常, $11 \mathrm{q} 23$ 異常, $3 \mathrm{q}$ 異常などは, NCCNでの化学療法でのリスク分類で は予後不良群に分類されているが，同種移植でのリ スクは中間群に分類されている。また， Kuwatsukaらは, 化学療法では子後良好群に分類 されるt（8；21）の同種移植における成績につい て，第 1 寛解期以外では染色体予後不良群と同等で あると報告しており ${ }^{13)}$, 化学療法と同種移植では, 個々の染色体のリスクが異なる可能性を示唆してい
る.しかし, 現時点において, 一定の頻度で発症し ている染色体異常を持つ疾患群についても十分な症 例数で解析できている報告はほとんどなく, 個々の 染色体異常の同種移植療法におけるリスク分類につ いては，今後の検討課題であると考えられる.

同種移植療法が化学療法と比較して, 白血病再発 抑制に対して有効に働く因子としては，化学療法・ 放射線療法の強化と移植後ドナー免疫担当細胞（T リンパ球やナチュラルキラー細胞など）による移植 片対白血病効果（GVL effect）が挙げられる ${ }^{15)}$. 現 時点で臨床的にGVL effectと同様の免疫反応によっ て生じる副作用であるGVHDを分けることは困難で ある。したがって，免疫反応の強度はGVHDの検討 によって代用されることが一般的である。そこで, 我々は染色体異常による層別化によって移植前処置 の強度をどのように設定し, 移植後免疫反応 (aGVHD, cGVHD）をどのようにマネージメントす べきかを検討するためサブグループ解析を行った (染色体子後良好群 +中間群を good risk group, 染 色体子後不良群をpoor risk groupと規定した)。そ の結果，移植前処置の強度については, good risk group・poor risk groupともに, PFS・RRにおい て有意な影響はなかった。この結果は, 特に good risk groupに対しては前処置を軽減してもRRを増 加させることなく, 患者負担の軽減が可能であるこ とを示唆する. poor risk groupに対して前処置を 軽減してもよいかについては, 後述する免疫反応と 再発時期の観点から難しい問題である. 移植後免疫 反応については, good risk groupとpoor risk groupにおいて対照的な結果となった. good risk groupでは, aGVHD (II-IV), cGVHD (広汎型) は ともには再発抑制に有利に働かず，PFSを下げる結 果で，GVHD予防を強化することが成績向上につな がることが示唆された. poor risk groupについて は, aGVHD (II-IV) は再発抑制に有利に働くとは 言えないがPFSに不利に働くことはなく, cGVHD (広汎型) は有意に再発を抑制LPFSを改善する結 果であった.つまり, poor risk groupでは, aGVHD を誘導することについては議論のあるところである が, cGVHDについては広汎型を誘導することが成 績改善につながる可能性があると考えられた。同様 の考えを支持する報告として, 予後不良の急性白血 病に対する移植後120日以降でのドナーリンパ球輸 
注によるGVL effect誘導での成績改善の報告もある ${ }^{16)}$.

今回の報告は少数例での後方視的解析であり断定 的な結論は出せないが，染色体リスクによる移植前 処置およびGVHD（GVL）の対応の層別化が, AML抢よびhigh risk-MDSの治療成績を向上させ る可能性があると考え報告した。

\section{参考文献}

1) Grimwade D, Moorman A, Hills R, Wheatley $\mathrm{K}$, Walker H, Harrison G, Harrison Ch, Goldstone A, Burnett A. NCRI Adult Leukaemia Working Party. Impact of karyotype on treatment outcome in acute myeloid leukemia. Ann Hematol 2004 ; 83 (Sup) : S45-S48.

2) Greenberg P, Cox C, LeBeau MM, Fenaux P, Morel P, Sanz G, Vallespi T, Hamblin T, Oscier D, Ohyashiki K, Toyama K, Aul C, Mufti G, Bennett J. International scoring system for evaluating prognosis in myelodysplastic syndromes. Blood 1997 ; 89 : 2079-2088.

3 ) A predictive model for aggressive nonHodgkin's lymphoma. The International nonHodgkin's Lymphoma Prognostic Factor Project. N Engl J Med 1993 ; 329 : 987-994.

4 ) Sorror ML, Maris MB, Storb R, Baron F, Sandmaier BM, Maloney DG, Storer B. Hematopoietic cell transplantation (HCT) specific comorbidity index : a new tool for risk assessment before allogeneic HCT. Blood $2005 ; 106: 2912-2919$.

5 ) Przepiorka D, Weisdorf D, Martin P, Klingemann HG, Beatty P, Hows J, Thomas ED. 1994 Consensus conference on acute GVHD grading. Bone Marrow Transplant $1995 ; 15: 825-855$.

6 ) Shulmann H, Sullivan KM, Weiden PL, McDonald GB, Striker GE, Sale GE, Hackman R, Tsoi MS, Storb R, Thomas ED. Chronic graft-versus-host disease in man : A clinic pathologic study of 20 long term Seattle patients. Am J Med 1980 ; 69 : 204-217.

7 ) Clift RA, Buckner CD, Appelbaum FR, Schoch G, Petersen FB, Bensinger WI, Sanders J, Sullivan KM, Storb R, Singer J. Allogeneic marrow transplantation during untreated first relapse of acute myeloid leukemia. J Clin Oncol $1992 ; 10$ : 1723-1729.

8 ) Kebriaei P, Kline J, Stock W, Kasza K, Le Beau MM, Larson RA, van Besien K. Impact of disease burden at time of allogeneic stem cell transplantation in adults with acute myeloid leukemia and myelodysplastic syndromes. Bone Marrow Transplant 2005 ; $35: 965-970$.

9) Slovak ML, Kopecky KJ, Cassileth PA, Harrington DH, Theil KS, Mohamed A, Paietta E, Willman CL, Head DR, Rowe JM, Forman SJ, Appelbaum FR. Karyotypic analysis predicts outcome of preremission and postremission therapy in adult acute myeloid leukemia : a Southwest Oncology Group/Eastern Cooperative Oncology Group Study. Blood $2000 ; 96: 4075-4083$.

10) Grimwade D, Walker H, Oliver F, Wheatley K, Harrison C, Harrison G, Rees J, Hann I, Stevens R, Burnett A, Goldstone A. The importance of diagnostic cytogenetics on outcome in AML : analysis of 1,612 patients entered into the MRC AML 10 trial. The Medical Council Adult and Children's Leukaemia Working Parties. Blood 1998 ; $92: 2322-2333$.

11) Ferrant A, Labopin M, Frassoni F, Prentice HG, Cahn JY, Blaise D, Reiffers J, Visani G, Sanz MA, Boogaerts MA, Löwenberg B, Gorin NC. Karyotype in acute myeloblastic leukemia : prognostic significance for bone marrow transplantation in first remission: a European Group for Blood and Marrow Transplantation study. Acute Leukemia Working Party of the European Group for Blood and Marrow Transplantation (EBMT). 
Blood 1997 ; 90 : 2931-2938.

12) Ogawa $H$, Ikegame $K$, Kawakami M, Takahashi S, Sakamaki H, Karasuno T, Sao H, Kodera Y, Hirabayashi N, Okamoto S, Harada M, Iwato K, Maruta A, Tanimoto M, Kawa K. Japan Society for Hematopoietic Cell Transplantation. Impact of cytogenetics on outcome of stem cell transplantation for acute myeloid leukemia in first remission : a largescale retrospective analysis of data from Japan Society for Hematopoietic Cell Transplantation. Int J Hematol $2004 ; 79$ : 495-500.

13) Kuwatsuka Y, Miyamura K, Suzuki R, Kasai M, Maruta A, Ogawa H, Tanosaki R, Takahashi S, Koda K, Yago K, Atsuta Y, Yoshida T, Sakamaki H, Kodera Y. Hematopoietic stem cell transplantation for core binding factor acute myeloid leukemia : t $(8 ; 21)$ and inv (16) represent different clinical outcomes. Blood $2009 ; 113$ : 20962103.

14) Armand P, Kim HT, DeAngelo DJ, Ho VT, Cutler CS, Stone RM, Ritz J, Alyea EP, Antin JH, Soiffer RJ. Impact of cytogenetics on outcome of de novo and therapy-related AML and MDS after allogeneic transplantation. Biol Blood Marrow Transplant 2007 ; 13 : 655-664.

15) Kolb HJ. Graft-versus-leukemia effects of transplantation and donor lymphocytes. Blood $2008 ; 112$ : 4371-4383.

16) Schmid C, Schleuning M, Ledderose G, Tischer J, Kolb HJ. Sequential Regimen of Chemotherapy, Reduced Intensity Conditioning for Allogeneic Stem-Cell Transplantation, and Prophylactic Donor Lymphocyte Transfusion in High-Risk Acute Myeloid Leukemia and Myelodysplastic Syndrome. J Clin Oncol 2005 ; 23 : 5675-5687.
Retrospective Analysis of 50 Cases of First Allogeneic Transplantation for Acute Myelogenous Leukemia and High Risk Myelodysplastic Syndrome

Toshihiko ANDO, Yukinori NAKAMURA, Ryohei NAWATA, Toru TAKAHASHI, Noriyuki MITANI, Koji YAMASHITA, Yoshinori TANAKA, Mayumi TANAKA, Koichi ARIYOSHI, Jun NOMIYAMA, Masatoshi TSURU, Toshiaki YUJIRI and Yukio TANIZAWA

Endocrinology, Metabolism, Hematological Sciences and Therapeutics (Internal Medicine III.), Yamaguchi University Graduate School of Medicine, 1-1-1 Minami Kogushi, Ube, Yamaguchi 755-8505, Japan

\section{SUMMARY}

In this single center retrospective study, we studied 50 adults with acute myelogeneous leukemia (AML) $(\mathrm{n}=40)$ and myelodysplastic syndrome (MDS) $(n=10)$ who received first allogeneic hematopoietic stem cell transplantation (allo-HSCT) to determine pre-transplant prognostic factors. The median age of our patients was 41.4 years. Thirty two per cent of the patients were transplanted in non-remission and $44 \%$ have poor risk chromosomal abnormalities by National Comprehensive Cancer Network (NCCN) for AML and international prognostic scoring system (IPSS) for MDS. At 3 years, probabilities of overall survival, progression free survival, relapse rate and nonrelapse mortality rate were 48.8, 41.3, 38.9 and $27.8 \%$ for the whole cohort, respectively. The prognostic impact for several pre-transplant parameters was assessed by univariate and by multivariate analyses using the Cox regression model. As a result, we reached conclusions that poor risk chromosomal abnormality was the most important prognostic factor before 
transplantation. We divided a chromosomal risk into a group of good plus intermediate risk (good risk group) and a group of poor risk (poor risk group) and performed analysis. We obtained conclusions to consider by therapeutic stratification in a chromosome risk in allo-HSCT as well as chemotherapy. 